\title{
Serological Investigations of Brucellosis in Cattle, Farmers and Veterinarians in the Kars District of Turkey
}

\author{
S. OTLU, M. SAHIN, H. I. ATABAY, A. UNVER
}

Department of Microbiology, Faculty of Veterinary Medicine, University of Kafkas, Kars, Turkey

Received April 27, 2007

Accepted December 19, 2007

\begin{abstract}
Otlu S., M. Sahin, H. I. Atabay, A. Unver: Serological Investigations of Brucellosis in Cattle, Farmers and Veterinarians in the Kars District of Turkey. Acta Vet Brno 2008, 77: 117-121.

The prevalence of brucellosis was investigated in cattle, farmers and veterinarians in the Kars district of Turkey between 2004 - 2006. In order to achieve this, a total of 407 serum samples of cattle from 27 herds having history of abortions were examined for Brucella antibodies by RBPT and SAT. In addition, the sera collected from 246 farmers (130 males and 116 females) and 28 veterinarians in the same district were analysed serologically by RBPT, SAT and ELISA. Of the cattle sera analysed, $134(32.92 \%)$ and $141(34.64 \%)$ were determined as positive by RBPT and SAT, respectively. Thirty-two (13\%), $35(14.22 \%)$ and $44(17.88 \%)$ of the farmers' sera were found positive for brucellosis by RBPT, SAT and ELISA, respectively. There was no significant difference between sexes for Brucella seropositivity. Of the 28 sera from veterinarians, $13(46.42 \%)$ were positive by the three serological tests. The high prevalence of brucellosis both in cattle and humans suggests that brucellosis is common in this area. Preventive and control measures should be implemented and pursued more strictly to reduce and/or eradicate brucellosis from the area.
\end{abstract}

Brucellosis, cattle, farmers, veterinarians, serology

Brucellosis is an important zoonotic and endemic disease in many regions of Turkey. Although several control and eradication measures have been established, the disease continues to produce large economic losses especially in cattle and small ruminants and cause a serious public health problem in Turkey (Sumer et al. 2003; Genc et al. 2005). Farmers, veterinarians and others involved in animal handling are at a higher risk of direct inoculation (Torre et al. 1997; Taleski et al. 2002). Individuals who ingest unpasteurized dairy products especially from areas of endemic infection are at a significant risk of food-borne brucellosis (Kubuafor et al. 2000; Kose et al. 2006). National Control and Eradication Programme for Brucellosis in domestic animals run by the Ministry of Agriculture has been implemented in Turkey since 1984 . However, the prevalence of brucellosis still ranges from region to region throughout Turkey. Although the prevalence of brucellosis in humans was not investigated previously in the Kars district that is situated in the Northeast Anatolia Region of Turkey, it is the most prevalent in cattle, with a $20.8 \%$ prevalence rate in this district (Anonymous 2006). The Kars Region has 330.000 cattle population mainly raised on family-operated farms and this population makes up $3.2 \%$ of the total cattle population nationwide. Human population in this region is 352.000 and $75 \%$ of them deal in animal husbandry. The number of veterinarians in this region is 60 and 71, as clinicians and officers, respectively.

In the study, we aimed at determining the seroprevalence of brucellosis in the Kars district in cattle by Rose Bengal Plate Test (RBPT) and Serum Agglutination tests (SAT), farmers and veterinarians by RBPT, SAT and ELISA.

\section{Materials and Methods}

Human and cattle serum samples

This study was carried out between January 2004 and December 2006. A total of 407 blood samples were

Address for correspondence:

Salih Otlu

Department of Microbiology, Faculty of Veterinary Medicine

University of Kafkas, 36040 Kars, Turkey
Tel.: +90 4742426800

Fax: +904742426853

E-mail: salihotlu@hotmail.com

http://www.vfu.cz/acta-vet/actavet.htm 
collected from cattle with a history of abortion and known to be not vaccinated against brucellosis from 27 different villages in the Kars district. In addition, 246 blood samples were taken from farmers living in the region where the cattle blood samples were collected from and sera were taken from the 28 veterinarians practising in the same area. Of these farmer samples, 130 and 116 were from males and females, respectively. The serum samples were kept at $-20{ }^{\circ} \mathrm{C}$ until tested. In addition, the records of the Governmental Health Branch (GHB) were also investigated for cases of human brucellosis during the study period.

Serological detection of Brucella antibodies

Brucella abortus antigen used in the study both for RBPT and SAT was obtained from Pendik Veterinary Control and Research Institute, Istanbul, Turkey. Serum samples from both cattle and humans were tested using RBPT and SAT according to standard methods (Alton et al. 1988). Titration of 1/160 and higher in humans and 1/40 and higher in cattle were accepted as a positive test result in SAT. In addition IgG-ELISA purchased from a commercial company (IBL, Hamburg, Germany) for human sera was used following the manufacturer's instructions.

\section{Results}

Of the 407 sera obtained from cattle with a history of abortion, 134 (32.92\%) were determined positive by RBPT and 141 (34.64\%) by SAT (Table 1). A total of 246 sera collected from the farmers were examined in the present study. Of these, 32 (13\%), 35 $(14.22 \%)$ and $44(17.88 \%)$ were found positive against brucella antibodies by RBPT, SAT and ELISA, respectively. While 17, 19 and 24 of the 116 female sera were determined as positive 15, 16 and 20 of the 130 male sera were positive by RBPT, SAT and ELISA, respectively. In terms of sex, $15.38 \%$ of the males and $20.68 \%$ of the females were positive using ELISA. The differences between the sex groups were found statistically nonsignificant $\left(\chi^{2}=1.175 ; P=>0.05\right)$. Similar results were also obtained by the RBPT and SAT. The records of the GHB showed that 244 cases of brucellosis (136 female and 108 male) were diagnosed in humans belonging to various age groups during the study period. Of all the 28 blood serum samples collected from the veterinarians, 13 were found positive using all the three serological methods.

Table 1. Number and results of the serum samples analyzed by RBPT, SAT and ELISA

\begin{tabular}{|c|c|c|c|c|c|c|}
\hline \multirow{3}{*}{ Number of samples } & \multicolumn{6}{|c|}{ Assay and numbers of negative and positive serum samples } \\
\hline & \multicolumn{2}{|c|}{ RBPT } & \multicolumn{2}{|c|}{ SAT } & \multicolumn{2}{|c|}{ ELISA } \\
\hline & Neg & Pos. & Neg & Pos. & $\mathrm{Neg}$ & Pos. \\
\hline $\begin{array}{l}\text { Cattle } \\
407\end{array}$ & 273 & 134 & 266 & 141 & & \\
\hline $\begin{array}{l}\text { Farmers } \\
246\end{array}$ & 214 & 32 & 211 & 35 & 202 & 44 \\
\hline $\begin{array}{l}\text { Veterinarians } \\
28\end{array}$ & 15 & 13 & 15 & 13 & 15 & 13 \\
\hline
\end{tabular}

\section{Discussion}

Brucellosis is prevalent in some middle-eastern countries such as Iran, Iraq, Saudi Arabia, Egypt, Syria (Refai 2002) and some south-eastern European countries such as Greece, Italy and Spain (Godfroid 2002). Turkey borders with several of these countries and is situated within this geography. Therefore, Turkey lies within the risky area between Middle East and Europe.

Turkey takes up a large area and is divided into seven geographical regions. Various prevalence rates of brucellosis have been reported for human and cattle population from different parts of Turkey. In a study conducted in Middle Anatolia, the seroprevalence of brucellosis was determined as 3.2\% in farmers and $1 \%$ in randomly selected cattle (Apan et al. 2007). In another study performed in the same region, 4.8\% seropositivity 
of Brucella was reported for humans living in the rural area (Cetinkaya et al. 2005). The seroprevalence of brucellosis was found to be $6.2 \%$ among farmers in East Anatolia by Sonmez et al. (1997) and from 2.9 to $8.5 \%$ seropositivity were reported for humans of rural and suburban communities in West Anatolia by Kose et al. (2006). Solmaz et al. (2002) analysed a total of 320 sera from randomly selected dairy cows in East Anatolia and found that $6.25 \%$ of the samples were positive for Brucella by RBPT. Iyisan et al. (2000) observed $1.43 \%$ seropositivity among randomly selected cattle from Middle Anatolia. According to data of Ministry of Agriculture, brucellosis is most prevalent in the Kars province, where this study was also carried out, in cattle with a prevalence rate of $20.8 \%$ (Anonymous 2006).

In the current study, the seroprevalence of brucellosis was determined to be $32.92 \%$ by RBPT and $34.64 \%$ by SAT in 407 serum samples of cattle collected from the herds with a history of abortions. In another study performed by our research group (Sahin et al. 2004), no clinical sign other than abortion and infertility was observed in animals with abortions, and B. abortus was isolated and identified from 35 of the $87(40.22 \%)$ aborted foetuses. This isolation rate is very high when compared to other studies conducted in various regions in Turkey and indicates that brucellosis is very common in this region. In previous studies performed in our laboratory in the same region, 55.2\% (Genc et al. 2005) and 33\% (Sahin et al. 2004) seropositivity was found in aborted cattle and randomly selected cattle from herds with a history of abortion, respectively. The reasons for this high prevalence might be explained by the fact that preventive measures are not implemented thoroughly and animal migration between Turkey and neighbouring countries such as Iraq, Iran and Syria where brucellosis is known to be endemic is not strictly controlled. In addition, the farmers in this district are not well-educated and seem uninterested in the prevention of their animals to these infectious diseases. Furthermore, animal breeding is performed as small-scale family farming, which may also hamper the control of infectious diseases. The detection of a higher rate of seropositivity in serum samples from the farmers as compared to other studies conducted in other regions in Turkey indicates that exposure to Brucella is more common. The records of the GHB also support this finding. The high prevalence of brucellosis in farmers determined in the current study can be explained by the fact that people involved in the study consume dairy products such as butter, white cheese and cream traditionally made of raw and/or insufficiently heated milk and are in a direct contact with the infected animals and their aborted foetuses and discharges. In terms of sex, no statistical difference was observed between males and females for the presence of brucellosis in farmers. This is not unexpected since both sexes consume similar food in the household and do the farm work together, such as animal care and nutrition. The high prevalence of brucellosis in veterinarians (13 positive out of 28) detected in the present study is important and surprising. When interviewed, most of the veterinarians found seropositive against Brucella in the current study claimed not to consume unpasteurized milk and/or dairy products. Therefore, transmission of Brucella to veterinarians might have occurred by direct contact with infected animals and intervention in some cases such as distorsion and retentio secundinarum. Therefore, veterinarians practising in the regions where brucellosis is known to be endemic should take adequate hygienic measures when contacting animals and their products.

It is concluded from the current study that brucellosis is highly prevalent in cattle and humans in the Kars district, situated in the north-eastern part of Turkey, where animal breeding is common. Preventive and control measures should immediately and strictly be implemented to protect animals and humans from brucellosis. In order to achieve this, domestic animals such as cattle, sheep and goat should be tested for brucellosis and seropositive animals should be slaughtered and sero-negative animals vaccinated 
systematically to efficiently eradicate brucellosis. Farmers should be educated about infectious animal diseases and small-scale family farming should be encouraged to perform more industrialized farming. National Control and Eradication Programme for Brucellosis run by the Ministry of Agriculture should be implemented more vigorously and cooperation established between Turkey and the neighbouring countries where brucellosis is also widespread. Furthermore, animal migration at the borders should be monitored. Large-scale studies are required in order to determine the exact epidemiology of brucellosis in humans and animals in this part of Turkey.

\section{Výskyt brucelózy u skotu, farmářů a veterinářů v Turecku, oblast Kars}

V letech 2004-2006 byla zjišt’ována prevalence brucelózy u skotu, farmářů a veterinářů v Turecku, oblast Kars. Vyšetřeno bylo 407 vzorků krevního séra skotu, který pocházel z 27 stád, u nichž se v minulosti vyskytly aborty. Tyto vzorky byly vyšetřeny na prrítomnost protilátek proti Brucella pomocí RBPT a SAT. Dále byly v této oblasti odebrány vzorky sér 246 farmářů (130 mužů a 116 žen) a od 28 veterinářů. Tyto vzorky byly analyzovány metodou RBPT, SAT a ELISA testem. Z testovaných vzorků u skotu bylo pozitivních $134(32,92 \%)$ metodou RBPT a $141(34,64 \%)$ metodou SAT. U farmářủ bylo na brucelózu pozitivních 32 (13\%) metodou RBPT, 35 (14,22 \%) metodou SAT a $44(17,88 \%)$ ELISA testem. Nebyly zjištěny signifikantní rozdíly v pozitivitě v závislosti na pohlaví. Z 28 vzorků sér veterinár̊o bylo $13(46,42 \%)$ pozitivních dle všech tří sérologických testů. Vysoká prevalence brucelózy jak u skotu tak i u lidí ukazuje, že v této oblasti je její výskyt běžný. K redukci nebo vymýcení výskytu brucelózy $v$ této oblasti by měla být zavedena a prŕsněji prosazována preventivní a kontrolní opatření.

\section{References}

ALTON GG, JONES LM, ANGUS RD, VERGER JM 1988: Techniques for brucellosis laboratory. Paris, INRA, pp. $123-130$

ANONYMOUS 2006: Prevalence of brucellosis in cattle in different provinces in Turkey. In: Report of prevention programme for animal diseases, Ministry of Agriculture of Turkey. Ankara, $33 \mathrm{p}$.

APAN T, YILDIRIM M, ISTANBULLUOGLU E, OZARSLAN B 2007: The studies on brucellosis seroprevalence at human, sheep and cattle populations in Kirıkkale. Turk J Vet Anim Sci 31: 75-78

CETINKAYA Z, AKTEPE OC, CIFTCI IH, DEMIREL R 2005: Seroprevalence of human brucellosis in a rural area of Western Anatolia, Turkey. J Health Popul Nutr 23: 137-141

GENC O, OTLU S, SAHIN M, AYDIN F, GOKCE HI 2005: Seroprevalence of brucellosis and leptospirosis in aborted dairy cows. Turk J Vet Anim Sci 29: 359-366

GODFROID J, KASBOHRER A 2002: Brucellosis in the European Union and Norway at the turn of twenty-first century. Vet Microbiol 90: 135-145

IYISAN AS, AKMAZ O, DUZGUN SG, ERSOY Y, ESKIIZMIRLILER S, GULER L, GUNDUZ K, IŞIK N, ICYEROGLU AK, KALENDER H, KARAMAN H, KARAMAN Z, KUCUKAYIN U, OZCAN C, SEYITOGLU S, TUNA I, TUNCA T, USTUNAKIN K, YURTALAN S 2000: Seroepidemiology of brucellosis on cattle and sheep in Turkey. J Pendik Vet Microbiol 31: 21-75

KOSE S, SMITS HL, ABDOEL TH, OZBEL Y 2006: Prevalence of brucella antibodies in rural and suburban communities in three provinces of Turkey: Need for improved diagnosis and prevention. J Infect 53: 308-314

KUBUAFOR DK, AWUMBILA B, AKANMORI BD 2000: Seroprevalence of brucellosis in cattle and humans in the Akwapim - South district of Gahana: public health implications. Acta Trop 76: 45-48

REFAI M 2002: Incidence and control of brucellosis in the Near East region. Vet Microbiol 90: 81-110

SAHIN M, ATABAY HI, OTLU S, UNVER A, CELEBI O 2004: Serological and cultural investigation of the prevalence of brucellosis in cattle, sheep and humans in Kars and its surrounding area. Proceedings of VI. National Congress of Veterinary Microbiology. Elazıg-Turkey, pp. 132-133

SOLMAZ H, TUTUNCU M, GULHAN T, EKIN IH, TASAL I 2002: The studies on the incidence of bovine brucellosis in Van Region. J Fac Vet Med Univ Y Y1l 13: 54-56

SONMEZ E, DURMAZ B, ALADAG M 1997: Brucellosis prevalence of Malatya (Turkey) province. Turk Med J 4: $102-5$

SUMER H, SUMER Z, ALIM A, NUR N, OZDEMIR L 2003: Seroprevalence of brucella in an elderly population in Mid-Anatolia, Turkey. J Health Popul Nutr 21: 158-161 
TALESKIV, ZERVAL, KANTARDJIEVT, CVETNICZ, ERSKI-BILJICM, NIKOLOVSKIB, BOSNJAKOVSKI J, KATALINIC-JANKOVIC V, PANTELIANDOU A, STOJKOSKI S, KIRANDZISKI T 2002: An overview of the epidemiology and epizootology of brucellosis in selected countries of Central and Southeast Europe. Vet Microbiol 90: 147-155

TORRE I, RIBERA G, PAVIA M, ANGELILLO IF 1997: A seroepidemiologic survey on brucellosis antibodies in Southern Italy. Infection 25: 150-153 
